\title{
SARS-CoV-2 antibodies titration: a reappraisal
}

\author{
Giuseppe Lippi ${ }^{1}$, Mario Plebani ${ }^{2}$ \\ ${ }^{1}$ Section of Clinical Biochemistry, University of Verona, Verona, Italy; ${ }^{2}$ Department of Laboratory Medicine, University Hospital of Padova, Padova, \\ Italy \\ Correspondence to: Prof. Giuseppe Lippi. Section of Clinical Biochemistry, University Hospital of Verona, Piazzale L.A. Scuro, 10, 37134 Verona, Italy. \\ Email: giuseppe.lippi@univr.it.
}

Submitted Jul 16, 2020. Accepted for publication Aug 14, 2020.

doi: 10.21037/atm-20-5361

View this article at: http://dx.doi.org/10.21037/atm-20-5361

Coronavirus disease 2019 (COVID-19), which is sustained by the acute respiratory syndrome coronavirus 2 (SARSCoV-2), has been definitely upgraded to pandemic pathology after affecting several millions people and causing hundreds thousand deaths all around the world (1). Unlike the previous two Coronaviruses epidemics, severe acute respiratory syndrome (SARS) and Middle-East respiratory syndrome (MERS), the progression of this new outbreak seems virtually unstoppable, overwhelming the response capacity of many healthcare systems worldwide and thus causing paramount clinical, economical and societal harms.

Despite the etiological diagnosis of SARS-CoV-2 infection remains essentially based on identification of viral RNA in biological materials, especially those obtained from the upper and lower respiratory tracts (2), serology testing is primary aimed at recognizing the presence of humoral response against the virus, for either epidemiological purposes (i.e., monitoring seroprevalence and/or herd immunity), or for occasionally complementing nucleic acid amplification tests (NAATs) in specific circumstances, for example when the test results of molecular diagnostics are undefined or may be falsely negative due to a vast array of pre-analytical and analytical issues $(3,4)$. Recent evidence is also emerging, that serology testing in COVID-19 may have additional and not less important clinical implications. The current armamentarium of immunoassays for measuring anti-SARS-CoV-2 antibodies encompass techniques which measure a single immunoglobulin class (i.e., IgM, IgG or IgA) or those measuring the "total immunoglobulins" response, as well as qualitative, semi-quantitative and quantitative methods (5). Although we would all agree that qualitative and semi-quantitative techniques are certainly adequate for epidemiologic purposes, clinical evidence is emerging that quantitative antibodies assessment (i.e., titration) may be more appropriate throughout the clinical course of COVID-19.

The first of such reasons is the strong and positive association that is being increasingly found between antibodies titer and disease severity, which distinguishes asymptomatic from symptomatic patients (6), but also predicts progression towards severe/critical illness (7). Although no definitive explanations have been provided so far for this intriguing biologic relationship, the development of antibody-dependent enhancement (ADE) has been advocated as one of the possible underlying mechanisms, whereby the humoral response against SARS$\mathrm{CoV}-2$, characterized by appearance of specific antibodies, may paradoxically contribute to amplify disease severity. More specifically, the viral particles bound to their specific antibodies may enhance viral entry within Fc $\gamma$ R-bearing cells, bypassing receptor-mediated pathways, which can then be followed by amplified viral replication, activation of immune cells and release into the bloodstream of a vast array of pro-inflammatory cytokines (i.e., mirrored by the so-called "cytokine storm"), which would ultimately contribute to trigger, sustain and propagate the systemic inflammatory reaction characterizing the unfavorable progression in COVID-19 (8). In this circumstance, the identification of patients with higher antibodies titer would enable to establish more appropriate therapies, for example based on early administration of antiviral and anti-inflammatory drugs aimed at preventing lung or disseminated organ injury (9). Quantitative assays would also allow a better reflection of neutralizing activity, more strictly associated with protection against SARSCoV-2 infection than measuring total antibodies (10), 
Table 1 Current indications for severe acute respiratory syndrome coronavirus 2 (SARS-CoV-2) serological testing

Epidemiology
Establishing seroprevalence
Monitoring herd immunity
Diagnosis
Complementing molecular biology in specific circumstances
Risk prediction
Monitoring nature and duration of humoral immunity

whilst non-neutralizing antibodies may provide also antiviral protection via recruitment of complement and/or Fc receptors, which are present on all immune cells (11).

Monitoring natural immunity is a second important reason, which specifically requires precise quantification of antibodies titer. Although it is by far too early to make conclusions on nature and duration of the host immune response against SARS-CoV-2 and on the effectiveness of virus neutralization over time as protection against the risk of re-infection, clear evidence has emerged that not only the anti-SARS-CoV-2 antibodies titer seems to decline quite rapidly in certain patients, but also that many patients with SARS-CoV-2 infection would become seronegative within 2-3 months after recovery. This notion is clearly supported by a seminal study published by Long et al. (12), who showed that the anti-SARS-CoV-2 antibodies titer declined in $81 \%$ and $62 \%$ of asymptomatic and symptomatic COVID-19 patients, respectively, in the convalescent phase (i.e., 8 weeks after hospital discharge). Even more importantly, as many as $40 \%$ and $13 \%$ of asymptomatic and symptomatic COVID-19 patients become seronegative on follow-up. It is hence rather understandable that longitudinal quantification of anti-SARS-CoV-2 antibodies titer seems almost unavoidable for monitoring the evolution of humoral response of patients recovering from COVID-19, for especially identifying those who will be at theoretically higher risk of being re-infected and, perhaps, of developing ADE.

The opportunity to adopt locally validated cut-offs for the different immunoassays is a third and more technical issue, which would justify specific anti-SARS-CoV-2 antibodies titration. A recent study by our group showed that local redefinition of diagnostic thresholds of different commercial methods may be necessary for optimizing test performance, but also for enhancing inter-assay agreement and improving harmonization of serological SARS-COV-2 testing worldwide (6).

Taken together, the current clinical (Table 1) and technical evidence around SARS-CoV-2 serology would strongly persuade us that anti-SARS-CoV-2 immunoassays not only should be characterized by high analytical sensitivity and dynamic detection range, but shall also be based on quantitative assessment of a single immunoglobulin class, rather than providing qualitative or semi-quantitative measures of the overall serological response.

\section{Acknowledgments}

Funding: None.

\section{Footnote}

Provenance and Peer Review: This article was commissioned by the Guest Editor (Giuseppe Lippi) for the series "Column in Laboratory Medicine" published in Annals of Translational Medicine. The article did not undergo external peer review.

Conflicts of Interest: Both authors have completed the ICMJE uniform disclosure form (available at http://dx.doi.org/10.21037/ atm-20-5361). The series "Column in Laboratory Medicine" was commissioned by the editorial office without any funding or sponsorship. GL serves as the unpaid Guest Editor of the series and serves as an unpaid executive editor-in-chief of Annals of Translational Medicine from Jan 2016 to Jan 2022. The authors have no other conflicts of interest to declare.

Ethical Statement: The authors are accountable for all aspects of the work in ensuring that questions related to the accuracy or integrity of any part of the work are appropriately investigated and resolved.

Open Access Statement: This is an Open Access article distributed in accordance with the Creative Commons Attribution-NonCommercial-NoDerivs 4.0 International License (CC BY-NC-ND 4.0), which permits the noncommercial replication and distribution of the article with the strict proviso that no changes or edits are made and the original work is properly cited (including links to both the formal publication through the relevant DOI and the license). See: https://creativecommons.org/licenses/by-nc-nd/4.0/. 


\section{References}

1. Lippi G, Sanchis-Gomar F, Henry BM. Coronavirus disease 2019 (COVID-19): the portrait of a perfect storm. Ann Transl Med 2020;8:497.

2. Lippi G, Plebani M. The critical role of laboratory medicine during coronavirus disease 2019 (COVID-19) and other viral outbreaks. Clin Chem Lab Med 2020;58:1063-9.

3. Bohn MK, Lippi G, Horvath A, et al. Molecular, serological, and biochemical diagnosis and monitoring of COVID-19: IFCC taskforce evaluation of the latest evidence. Clin Chem Lab Med 2020;58:1037-52.

4. Lippi G, Mattiuzzi C, Bovo C, et al. Current laboratory diagnostics of coronavirus disease 2019 (COVID-19). Acta Biomed 2020;91:137-45.

5. Deeks JJ, Dinnes J, Takwoingi Y, et al. Antibody tests for identification of current and past infection with SARSCoV-2. Cochrane Database Syst Rev 2020;6:CD013652.

6. Plebani M, Padoan A, Negrini D, et al. Diagnostic

Cite this article as: Lippi G, Plebani M. SARS-CoV-2 antibodies titration: a reappraisal. Ann Transl Med 2020;8(16):1032. doi: 10.21037/atm-20-5361 performances and thresholds: The key to harmonization in serological SARS-CoV-2 assays? Clin Chim Acta 2020;509:1-7.

7. Liu ZL, Liu Y, Wan LG, et al. Antibody profiles in mild and severe cases of COVID-19. Clin Chem 2020;66:1102-4.

8. Arvin AM, Fink K, Schmid MA, et al. A perspective on potential antibody-dependent enhancement of SARSCoV-2. Nature 2020;584:353-63.

9. Lippi G, Sanchis-Gomar F, Henry BM. COVID-19: unravelling the clinical progression of nature's virtually perfect biological weapon. Ann Transl Med. 2020;8:693.

10. Jääskeläinen AJ, Kuivanen S, Kekäläinen E, et al. Performance of six SARS-CoV-2 immunoassays in comparison with microneutralisation. J Clin Virol 2020;129:104512.

11. Zohar T, Alter G. Dissecting antibody-mediated protection against SARS-CoV-2. Nat Rev Immunol 2020;20:392-4.

12. Long QX, Tang XJ, Shi QL, et al. Clinical and immunological assessment of asymptomatic SARS-CoV-2 infections. Nat Med 2020;26:1200-4. 